\title{
PERSONAL SELLING DALAM PERSPEKTIF ISLAM
}

\author{
Fani Firmansyah \\ Program Diploma III Perbankan Syariah \\ Fakultas Ekonomi UIN Maulana Malik Ibrahim Malang \\ Jln. Gajayana 50 Malang \\ firmansyahfani@yahoo.co.id/ HP. 08165458793
}

\begin{abstract}
Abstrack
Currently the business world faces a new era of competition is very tight.For example in the trade industry, the strictness of a competition requirescompanies to be more active in promoting its products. By applying the strategy or the right marketing methods, business must be better prepared to deal with that era. Moreover in this era of globalization, appears a new phenomenon of global consumer (global consumers), as a result the company must improve competitiveness to maintain the continuity of their business through various improvements, both in terms of pricing, promotion, product quality, distribution, sales and service strategies . Represent improvements that must be done by a company, in terms of personal selling islami is a method appropriate promotional strategies to achieve corporate objectives in the face of this globalization era. In making a purchase, one will go through several stages of the buying decision process consisting of problem recognition, information search, alternative evaluation, purchase decision and behavior after purchase. With personal selling have direct effects that arise in face-to-face meetings between sellers and buyers, where there is communication of the necessary factors to influence the decision to purchase or use of psychological factors in order to persuade and to give courage to the time of purchase decisions with the goal of keeping the sales transaction
\end{abstract}

\section{Keywords : personal selling, marketing, salesman}

Perkembangan ekonomi dunia saat ini mengalami kemajuan yang sangat pesat sekali, diikuti oleh banyak munculnya perusahaan-perusahaan yang bergerak dibidang produksi barang maupun jasa yang dibarengi dengan semakin kompleksnya persoalan dan tingginya tingkat persaingan. Persoalan demi persoalan terus bersambungan tiada henti dan tingginya tingkat persaingan yang harus dihadapi oleh perusahaan-perusahaan saat ini secara tidak langsung perlu dilakukan langkah-langkah strategis oleh perusahaan dalam menghadapi persoalan-persoalan yang begitu kompleks dan tingginya tingkat persaingan. Segala upaya dalam menghadapi persoalan-persoalan yang begitu kompleks dan persaingan yang begitu tajam melalui berbagai macam cara dan metode oleh para pengambil keputusan di suatu 
perusahaan khususnya dalam menghadapi tingginya tingkat persaingan saat ini yaitu menerapkan bauran promosi yang tepat salah satunya personal selling (penjualan pribadi).

Pada saat situasi persaingan yang begitu ketat, personal selling (penjualan pribadi) menjadi perhatian khusus bagi manajemen perusahaan yang bergerak di bidang produksi barang maupun jasa. Personal selling (penjualan pribadi) merupakan suatu hal yang harus benar-benar diperhatikan oleh manajemen perusahaan saat ini,karena kalau pihak manajemen perusahaan salah dalam menerapkan personal selling (penjualan pribadi) secara tidak langsung akan berdampak negatif pada perusahaan. Oleh karena itu, pihak manajemen perusahaan harus menerapkan personal selling (penjualan pribadi) secara benar dan profesional supaya tujuan perusahaan tercapai.

Di zaman sekarang, kita melihat beberapa media cetak maupun elektronik telah terjadi banyak penipuan yang dilakukan oleh seorang marketer di perusahaan yang bergerak dibidang jasa dan barang,salah satu contoh kasus besar yang sekarang membikin banyak perhatian masyarakat, yaitu kasusnya Melinda Dee karyawan Citibank yang menjabat sebagai relationship manager (marketing). Dalam kasus ini melinda dee dituduh menggelapkan dana nasabah sebesar Rp.17 milyar dengan berbagai cara yang tidak sesuai dengan nilai-nilai Islam. Pada kasus ini pihak perusahaan yaitu citibank pasti secara tidak langsung terkena dampaknya yaitu citra perusahaan akan buruk dan dalam jangka panjang akan mempengaruhi bisnisnya.

Pada saat ini kita sering melihat banyak terjadi kasus-kasus penipuan yang dilakukan oleh oknum-oknum karyawan yang berposisi sebagai marketer di perusahaan yang bergerak di bidang produksi barang atau jasa kepada para pelanggannya atau nasabahnya, maka dari itu timbul suatu pertanyaan, strategi personal selling apa yang bisa meminimalisir kasuskasus penipuan yang dilakukan oleh seorang marketer kepada konsumennya.

\section{Definisi Personal Selling}

Personal selling merupakan salah satu komponen promotion mix di samping advertising, publicity dan sales promotion yang menekankan pada komunikasi yang bersifat persuasif untuk dapat menggugah kemungkinan konsumen untuk melakukan pembelian. Menurut Imam (2010), personal selling (penjualan pribadi) adalah kegiatan promosi yang dilakukan dengan melakukan penjualan secara pribadi kepada pelanggan. Dalam personal selling (penjualan pribadi) terjadi sentuhan langsung antara tenaga pemasaran dengan 
pelanggan akhir, sehingga memungkinkan terjadinya kontak langsung. Saat kontak langsung itulah dapat digali beberapa hal untuk kegiatan pemasaran lainnya.

Amstrong (2011) mengatakan bahwa personal selling adalah presentasi pribadi oleh para wiraniaga (tenaga penjual) perusahaan dalam rangka mensukseskan penjualan dan membangun hubungan dengan pelanggan. Sedangkan menurut Mc Daniel (2011), personal selling merupakan komunikasi langsung antara perwakilan penjual dengan satu atau lebih calon pembeli dalam upaya untuk mempengaruhi satu dengan lainnya dalam situasi pembelian. Tjiptono (2000) berpendapat bahwa personal selling merupakan komunikasi langsung (tatap muka) antara penjual dan calon pelanggan untuk memperkenalkan suatu produk kepada calon pelanggan dan membentuk pemahaman pelanggan terhadap suatu produk sehingga mereka kemudian akan mencoba membelinya.

Dari beberapa definisi diatas dapat disimpulkan bahwa personal selling adalah promosi penjualan yang dilakukan dengan dua arah dan dinilai lebih efektif dalam memasarkan produk, karena tujuan akhirnya dalam suatu promosi adalah melakukan penjualan. Selain itu personal selling merupakan aktivitas komunikasi antara produsen yang diwakili oleh tenaga penjual dengan konsumen potensial yang melibatkan pikiran dan emosi, serta tentu saja berhadapan langsung (face to face).

\section{Tujuan Personal Selling}

Tujuan personal selling sangat beragam, mulai dari sekedar membangkitkan kesadaran mengenai tersedianya produk, menggairahkan minat pembeli, sampai dengan membandingkan harga dan syarat-syarat jual beli serta penyelesaian transaksi. Shimp (2000) menyebutkan tujuan personal selling ada mendidik para pelanggan, menyediakan produk yang berguna dan bantuan pemasaran, serta memberikan pelayanan purna jual dan dukungan kepada pembeli

Berdasarkan uraian diatas dapat disimpulkan bahwa tujuan personal selling selain untuk meningkatkan penjualan juga mempertahankan loyalitas pelanggan, memberikan pelayanan teknis dan mengkomunikasikan informasi produk sepenuhnya berhubungan dengan sasaran pemasaran yang lebih luas yaitu mempertahankan dan meningkatkan penjualan terhadap pelanggan sekarang.

\section{Kriteria Personal Selling}


Penjual yang ditugaskan untuk melakukan personal selling harus memenuhi kriteria sebagai berikut, Tjiptono (2000); (a) Salesmanship, seorang personal selling harus mempunyai pengetahuan mengenai produk dan seni menjual antara lain cara mendekati pelanggan, mengatasi klaim pelanggan, mengatasi klaim pelanggan, melakukan presentasi, maupun cara meningkatkan penjualan. (b) Negotiating, seorang personal selling diharapkan mempunyai kemampuan dalam melakukan negosiasi dengan disertai syarat-syaratnya. (c) Relationship marketing, seorang personal selling harus mengetahui cara membina dan memelihara hubungan baik dengan para pelanggan.

Dalam personal selling, calon pelanggan atau pembeli diberikan suatu edukasi terhadap produk yang ditawarkan atau ditunjukkan bagaimana perusahannya dapat membantu pelanggan untuk mendapatkan keuntungan dari produk yang ditawarkan maupun keuntungan secara finansial dengan menjadi bagian di dalamnya (menjadikan pelanggan sebagai mitra, sebagai simbiosis yang saling menguntungkan)

\section{Strategi Personal Selling}

Strategi personal selling menurut Kotler (1995:191) adalah sebagi berikut; (a) Salesman dengan pembeli adalah salesman bercakap-cakap dengan calon pembeli atau pelanggan secara pribadi. (b) Salesman dengan kelompok pembeli adalah salesman melakukan presentasi dihadapan kelompok pembeli. (c) Tim penjual dengan kelompok pembeli adalah seorang dengan tim leader yang melakukan presentasi penjualan di hadapan kelompok pembeli. (d) Penjualan melalui konferensi adalah salesman membawa para narasumber yang berasal dari perusahaan datang bertemu dengan seorang pembeli atau lebih untuk membahas berbagai masalah dan peluang. (e) Penjualan melalui seminar, dalam hal ini adalah sebuah tim yang berasal dari perusahaan melakukan seminar pendidikan bagi kelompok teknisi yang diadakan perusahaan langganan mengenai perkembangan produk perusahaan.

Para tenaga penjual merupakan ujung tombak perusahaan dalam menjalin relasi dengan pelanggan. Bahkan sebagian pelanggan,tenaga penjual adalah perusahaan itu sendiri. Tenaga penjual juga banyak memberikan informasi umpan balik mengenai pelanggan pesaing. Oleh karena itu, perusahaan harus mempertimbangkan secara cermat keputusan menyangkut armada penjualannya; tujuan dan strategi, struktur (berdasarkan teritorial, produk, pasar dan kombinasinya), ukuran (dengan mempertimbangkan beban kerja) dan kompensasi. 


\section{Proses Personal Selling Islami}

\section{Pendekatan (approach)}

Yaitu proses personal selling di mana tenaga penjual bertemu dan menyapa pembeli untuk mendapatkan hubungan atau untuk memulai suatu awal yang baik. Langkah ini melibatkan penampilan tenaga penjual, kata-kata pembukaan, dan penjelasan lanjut. Oleh karena itu, penting bagi tenaga penjual untuk memberikan kesan pertama yang baik kepada calon pelanggan sebagaimana hadits Nabi Muhammad saw. yang berbunyi: "Senyummu di muka saudaramu merupakan sedekah bagimu" (HR.Riwayat Bukhari).

Selain itu kesan pertama yang perlu dilakukan seorang tenaga penjual pada tahap pendekatan, seperti yang tercantum dalam surat Thaha Ayat 44: "Maka berbicaralah kamu berdua kepadanya dengan kata-kata yang lemah lembut,mudah-mudahan ia ingat dan takut". Bila saudara seiman, umat islam diminta rasul untuk tersenyum atau bersikap ramah ia juga mendapatkan pahala, apalagi bagi seorang pedagang muslim. Persoalan keramahan itu, bukan sekedar dengan kegiatan usahanya. Karena keramahan pengusaha atau pedagang merupakan salah satu daya tarik bagi konsumen. Dengan kesan yang lebih positif, ini merupakan awal yang baik bagi penjual untuk berinteraksi dengan konsumen.

\section{Presentasi (presentation)}

Proses personal selling dimana tenaga penjual menceritakan riwayat produk kepada pembeli, menunjukkan bagaimana produk akan menghasilkan atau menghemat uang bagi pembeli. Tenaga penjual menguraikan fitur-fitur produk bagi pelanggan. Menggunakan pendekatan kepuasan kebutuhan. Biasanya mereka menjelaskan fitur-fitur penting dari produknya, menonjolkan kelebihan-kelebihannya dan menyebutkan contoh-contoh kepuasan konsumen. Oleh karena itu pada saat presentasi, tenaga penjual harus dipersiapkan dengan baik, dilatih kembali apa yang mereka katakan, menggunakan kontak mata langsung, bertanya dengan pertanyaaan terbuka dan bersikap tenang.

Meskipun demikian,dalam mempresentasikan suatu produk diharapkan untuk berbicara jujur dan bisa memenuhi janji-janjinya. Allah berfirman dalam surat Ali Imran ayat 77: "Sesungguhnya orang-orang yang menukar janji (nya dengan) allah dan sumpah-sumpah mereka dengan harga yang sedikit,mereka itu tidak mendapat bahagian (pahala) di akhirat." Diterangkan pula dalam hadist HR.Ibnu Majah : "Muslim adalah saudara muslim tidak boleh 
bagi seorang muslim apabila ia berdagang dengan saudaranya dalam memakan cacat,kecuali diterangkan"

Dari uraian ayat al-Quran dan hadits di atas, jelas memerintahkan umat Islam untuk jujur termasuk dalam berbisnis. Dengan sikap kejujuran, pembeli akan bertambah karena Allah swt. akan memberikan kelebihan pada orang jujur itu. Sedangkan pembeli tentu juga akan memberikan informasi tentang kejujuran dan kebaikan pedagang itu kepada yang lain,sehingga pembelinya bertambah. Selain itu hadist Nabi saw. juga mengajarkan bermurah hati ketika menjual: "Allah menyayangi seseorang yang bermurah hati ketika menjual, ketika membeli dan ketika mengadakan penagihan" (H.R Bukhari ). Sifat jujur, menepati janji dan bermurah hati bisa menguntungkan penjual karena konsumen tidak akan merasa kecewa setelah melakukan pembelian. Mereka akan percaya apa yang dikatakan penjual, sehingga tidak akan takut bila melakukan pembelian ulang.

\section{Mengatasi Keberatan (Handing Objection)}

Yaitu proses personal selling di mana tenaga penjual melakukan menyelidiki, mengklarifikasi, mengatasi keberatan pelanggan untuk membeli. Selama presentasi, pelanggan hampir selalu mempunyai keberatan. Demikian juga sewaktu mereka diminta untuk menuliskan pesanan. Masalahnya bisa logis, bisa juga psikologis, dan keberatan saling tidak diungkapkan keluar. Dalam mengatasi keberatan, tenaga penjual harus menggunakan pendekatan positif, menggali keberatan yang tersembunyi, meminta pembeli untuk menjelaskan keberatan, menggunakan keberatan sebagai peluang untuk memberikan informasi yang banyak dan mengubah keberatan menjadi alasan membeli. Setiap tenaga penjual membutuhkan pelatihan dalam hal-hal mengatasi keberatan.

Penanganan Keberatan ini juga dibahas dalam Islam, seperti sabda Nabi saw. sebagai berikut: "Dan barang siapa yang memberikan kemudahan kepada orang yang kesulitan maka Allah akan memberikannya kemudahan di dunia dan di akhirat". (HR. Bukhari). Hadist ini menunjukkan bahwa apabila seorang penjual memberikan kemudahan atas keberatan yang dirasakan konsumen,maka konsumen akan lebih puas karena merasa diperhatikan dan dilayani lebih intensif. Langkah ini bisa berubah menjadi tahap positif dari proses penjualan karena menyediakan peluang kepada tenaga penjualan untuk menyediakan informasiinformasi tambahan dan menawarkan solusi yang unik sebagai salah satu cara untuk mengklarifikasi keberatan-keberatan yang muncul. 


\section{Menutup Penjualan (Clossing)}

Yaitu proses personal selling di mana tenaga penjual apa yang hendak dipesan oleh pelanggan. Setelah mengatasi keberatan prospek, sekarang tenaga penjual dapat mencoba menutup penjualan. Tenaga penjual harus mengetahui tanda-tanda penutupan dari pembeli termasuk gerakan fisik, komentar dan pertanyaan. Sebagai contoh, pelanggan mungkin duduk condong ke depan dan mengangguk menyetujui atau menanyakan harga dan syarat pembayaran kredit.

Tenaga penjual tidak diperbolehkan memaksa konsumen secara berlebihan. Konsumen berhak memilih dan memutuskan apakah ia jadi melakukan pembelian atau tidak. Seperti yang diterangkan dalam hadist Nabi Muhammad saw. Diriwayatkan oleh Ishak dari Hibban dari Hammam dari Qotadah dari Abi Khalil dari Abdullah bin Haris, dari Hakim bin Hisyam, sesungguhnya Nabi Muhammad saw. telah bersabda: "Penjual dan pembeli berhak memilih (barang yang diperjualbelikan) selama mereka masih belum terpisah, Hamam berkata: dalam catatan saya hal ini (memilih) dilakukan sampai tiga kali”, maka apabila kedua belah pihak mengatakan yang sebenarnya dan menjelaskan kualitas masing-masing, dan apabila berbohong atau menyembunyikan(dalam transaksi) sehingga menguntungkan keduanya maka transaksi itu akan menghapus keberkahan antara keduanya."(HR.Bukhari).

Bila konsumen tidak jadi melakukan pembelian, diharapkan penjual tetap berperilaku baik dan sopan, seperti firman Allah dalam surat al Isra' ayat 28: “Dan jika kamu berpaling dari mereka untuk memperoleh rahmat dari Tuhanmu yang kamu harapkan maka katakanlah kepada mereka ucapan yang pantas.”. Hadist dan ayat di atas telah menerangkan pentingnya bagi penjual untuk memberikan kesempatan kepada konsumen untuk memutuskan apa ia jadi melakukan pembelian atau tidak dan agar penjual bersikap sopan meskipun transaksi penjualan tidak jadi dilakukan. Karena transaksi bisnis tidak bisa dikatakan mencapai sebuah bentuk perdagangan yang saling rela antara pelakunya, jika di dalamnya masih ada tekanan atau penipuan yang digunakan oleh salah satu pihak yang melakukan transaksi. Itulah sebabnya mengapa Al-Quran mengecam dan melarang praktek-praktek yang demikian tersebut.

\section{Hubungan Personal Selling dengan Konsumen}

Dalam konteks hubungan personal selling dengan konsumen yang akan melakukan transaksi pembelian, efektifitas dari strategi pemasaran dapat ditunjukkan dengan kemampuannya mempengaruhi dan merubah aktivitas konsumen untuk mencapai apa yang 
menjadi sasaran dari strategi pemasaran. personal selling merupakan bagian dari strategi pemasaran yang diarahkan untuk mempengaruhi perilaku konsumen terutama dalam melakukan keputusan untuk pembelian.

Swastha dan Irawan (2000) mengatakan bahwa dalam personal selling terjadi interaksi secara langsung saling bertatap muka. Komunikasi yang dilakukan kedua belah pihak bersifat individual dan dua arah sehingga dapat langsung memperoleh tanggapan sebagai umpan balik tentang kebutuhan dan keinginan pembeli. Adanya interaksi langsung ini dapat oleh penjual untuk membujuk dan mempengaruhi konsumen untuk melakukan keputusan pembelian sehingga terjadi transaksi pembelian.

Selain itu Assauri (2004) berpendapat dengan personal selling terdapat pengaruh secara langsung yang timbul dalam pertemuan tatap muka antara penjual dan pembeli, di mana terdapat pengkomunikasian fakta yang diperlukan untuk mempengaruhi keputusan pembelian atau menggunakan faktor psikologis dalam rangka membujuk dan memberikan keberanian pada waktu pembuatan keputusan pembelian dengan tujuan agar terjadi transaksi penjualan

Pada dasarnya konsumen baru akan melakukan pembelian apabila ia sudah mengetahui karakteristik produk. Pada tahap selanjutnya, bila konsumen sudah tertarik pada suatu produk dan mulai mengadakan pembelian, maka perlu kiranya diingatkan akan manfaat produk yang sudah dinikmatinya sehingga diharapkan konsumen melakukan pembelian secara berulang. Oleh karena itu, dengan personal selling diharapkan calon pembeli dapat mengenal lebih banyak produk yang dihasilkan perusahaan dan pada akhirnya dapat menimbulkan ketertarikan akan produk yang ditawarkan oleh perusahaan. Semakin tinggi kunjungan yang dilakukan oleh penjual pada konsumen, maka semakin tinggi kemungkinan produk yang akan terjual. Dalam hal ini, kemampuan tenaga penjual juga sangat menentukan terjadinya transaksi penjualan. Dengan demikian dapat disimpulkan bahwa personal selling mempunyai peranan besar yang sangat besar untuk mempengaruhi keputusan konsumen dalam melakukan transaksi pembelian.

\section{KESIMPULAN}

Dari pembahasan di atas bisa disimpulkan bahwa personal selling (penjualan pribadi) merupakan hal sangat penting yang harus diperhatikan, karena bersentuhan langsung dengan pelanggan dan kalau salah dalam menerapkan dalam arti mengabaikan nilai-nilai Islam dalam jangka panjang akan berdampak negatif pada perusahaan. Dalam menerapkan personal selling (penjualan pribadi) yang harus diperhatikan oleh pihak manajemen perusahaan adalah 
nilai-nilai islam yang harus ditekankan kepada setiap karyawannya supaya bisa mencegah dan meminimalisasi tindak penipuan terhadap pelanggan.

Dengan menerapkan personal selling (penjualan pribadi) yang islami pada perusahaan dalam jangka panjang akan membawa dampak positif terhadap perusahaan dalam arti image perusahaan dipersepsi para pelanggan dan masyarakat akan baik dan otomatis akan meningkatkan penjualan perusahaan itu sendiri.

\section{DAFTAR PUSTAKA}

Al-Quran dan terjemahannya, 2009. Komplek Percetakan Al-Quran Raja Fahd.

Amirullah, 2002. Perilaku Konsumen, Cetakan Pertama, Graha Ilmu, Yogyakarta.

Assauri, Sofyan, 2004. Manajemen Pemasaran Dasar Konsep dan Strategi, PT Raja Grafindo Persada, Jakarta.

Boone dan Kurtz, 2002. Pengantar Bisnis. Jilid 2, Alih Bahasa Fradinsyah Anwar, et. all., Erlangga, Jakarta.

Chandra, Gregorius, 2005. Strategi dan Program Pemasaran, ANDI, Yogyakarta.

Kotler dan Amstrong, 2001. Prinsip-Prinsip Pemasaran, Jilid 2, Ahli Bahasa Damos Sihombing. Erlangga. Jakarta

Kotler, Philip, 1995. Manajemen Pemasaran : Analisis, Perencanaan,Implementasi dan Pengendalian, Jilid 1, Alih Bahasa AncellaAnitawati H, Salemba Emapat, Jakarta.

Kusumadmo, 1985. Keputusan Pemasaran. Liberty, Yogyakarta

Lancaster, Geoffrey, 1990. Teknik dan Manajemen Penjualan, Alih Bahasa Kirbrandoko, Binarupa Aksara, Jakarta.

Mc Carthy dan Perrefault, 1996. Dasar-Dasar Pemasaran, Alih Bahasa Agus Dharma, Erlangga, Jakarta.

Mc Daniel, Lamb Hair, 2001. Pemasaran, Jilid 2, PT Salemba Emban Patria,Jakarta.

Santoso, Benny, 2002. All About MLM, memahami lebih jauh MLM dan pernakperniknya. Penerbit Andi, Yogyakarta

Shimp, Terence A, 2000. Periklanan Promosi dan Aspek Tambahan KomunikasiPemasaran Terpadu, Jilid 2, Alih Bahasa Oleh Dwi Kartini, Erlangga, Jakarta. 
Stanton, W. J, 1978. Fundamentals Of Marketing, Alih Bahasa Moh. IdichiAnwar, Alumni, Bandung.

Swastha, Basu dan Irawan, 2000. Manajemen Pemasaran Modern, Liberty, Yogyakarta.

Tjiptono, Fandy, 2000. Strategi Pemasaran, Edisi Ketiga, ANDI, Yogyakarta.

Walker, Boyd L, 1997. Manajemen Pemasaran, Jilid 1, Alih Bahasa Oleh ImamNurmawan, Erlangga, Jakarta. 